\title{
УДК 656.222.3
}

\section{Т. В. БУТЬКО ${ }^{1 *}$, Г. О. ПРОХОРЧЕНКО ${ }^{2 *}$}

$1^{*}$ Каф. «Управління експлуатаційною роботою», Український державний університет залізничного транспорту, майдан Фейєрбаха, 7, м. Харків, Україна, 61166, (057) 730 19 88, ел. пошта uermp@ukr.net, ORCID 0000-0002-6707-4552

${ }^{2 *}$ Каф. «Управління експлуатаційною роботою», Український державний університет залізничного транспорту, майдан Фейєрбаха, 7, м. Харків, Україна, 61166, (057) 73019 88, ел. пошта galaproh@ meta.ua, ORCID 0000-0003-1158-3953

\section{ФОРМУВАННЯ ПРОЦЕДУРИ АВТОМАТИЗАЦІЇ РОЗРОБКИ ГРАФІКУ РУХУ ПОЇЗДІВ НА ОСНОВІ АЛГОРИТМУ ШТУЧНИХ БДжОЛИНИХ КОЛОНІЙ}

Мета. Робота присвячена питанню автоматизації нормативного графіку руху поїздів на основі застосування сучасних методів оптимізації. В умовах реформування залізничного транспорту та утворення нових підприємств різних форм власності необхідним є перегляд існуючих підходів до складання графіку руху поїздів (ГРП), що є одним із основних документів щодо ефективності використання пропускної спроможності залізничної інфраструктури. Графік руху поїздів стає не тільки основним технологічним документом для внутрішнього користування, але і визначальною частиною договору між перевізниками та власниками інфраструктури і вирішення задачі автоматизації розробки ГРП є одним з найважливіших завдань планування і управління роботою залізничного транспорту. Методика. 3 метою вирішення поставленого завдання в роботі було сформовано математичну модель складання графіка руху поїздів, яка орієнтована на отримання мінімуму сумарних витрат на вартість непродуктивних простоїв всіх поїздів на дільниці, витрат на зупинки поїздів і вартості штрафу за невиконання директивних строків прямування поїздів через дільницю відповідно до заявок операторів. Одночасне прокладання великої кількості поїздів зводиться до комбінаторної задачі, що відноситься до класу NP-складних. Результати. Для рішення запропонованої математичної моделі в роботі запропоновано застосувати один з методів мультиагентної оптимізації - алгоритм штучних бджолиних колоній (англ., Artificial Bee colony Algorithm, ABC) , який базується на моделюванні поведінки бджіл у природному середовищі. Експериментальні розрахунки показали ефективність застосування алгоритму АВС для автоматизації ГРП. Наукова новизна. Вперше алгоритм штучних бджолиних колоній було адаптовано до рішення задачі автоматизованої побудови графіку руху вантажних поїздів на одноколійній дільниці. Практична значимість. Застосування алгоритму АВС при складанні та корегуванні нормативного графіку руху поїздів дозволить розробити нові системи підтримки прийняття рішень інженерних працівників на основі WEB-технологій,підвищити точність складання ГРП та його ефективність, а також надасть можливість корегування в оперативному порядку при безумовному задоволенні потреб в перевезенні вантажів та пасажирів.

Ключові слова: графік руху поїздів, мультиагентна оптимізація, пропускна спроможність.

Цель. Работа посвящена вопросу автоматизации нормативного графика движения поездов на основе применения современных методов оптимизации. В условиях реформирования железнодорожного транспорта и образования новых предприятий различных форм собственности необходимо пересмотр существующих подходов к составлению графика движения поездов (ГРП), что является одним из основных документов по эффективности использования пропускной способности железнодорожной инфраструктуры. График движения поездов становится не только основным технологическим документом для внутреннего пользования, но и определяющей частью договора между перевозчиками и владельцами инфраструктуры и решения задачи автоматизации разработки ГРП является одной из важнейших задач планирования и управления работой железнодорожного транспорта. Методика. С целью решения поставленной задачи в работе было сформировано математическую модель составления графика движения поездов, ориентированной на получение минимума суммарных расходов на стоимость непроизводительных простоев всех поездов на участке, расходов на остановки поездов и стоимости штрафа за невыполнение директивных сроков следования поездов через участок согласно заявкам операторов. Одновременное прокладывание большого количества поездов сводится к комбинаторной задачи, относится к классу NP-сложных. Результаты. Для решения предложенной математической модели в работе предложено применить один из методов мультиагентной оптимизации - алгоритм искусственных пчелиных колоний (англ., Artificial Bee colony Algorithm, ABC), основанный на моделировании поведения пчел в естественной среде. Экспериментальные расчеты показали эффективность применения алгоритма АВС для автоматизации ГРП. Научная новизна. Впервые алгоритм искусственных пчелиных колоний был адаптирован к решению задачи автоматизированного построения графика движения грузовых поездов на однопутном участке. Практическая значимость. Применение алгоритма АВС при 
составлении и корректировке нормативного графика движения поездов позволит разработать новые системы поддержки принятия решений инженерных работников на основе WEB технологий, повысить точность сборки ГРП и его эффективность, а также предоставит возможность корректировки в оперативном порядке при безусловном удовлетворении потребностей в перевозке грузов и пассажиров.

Ключевые слова: график движения поездов, мультиагентная оптимизация, пропускная способность.

Purpose. The work is devoted to automation of the regulatory timetable of trains on the basis of application of modern methods of optimization. In the context of reforming the railway transport and the formation of new enterprises of different ownership forms need to review the current approaches to the compilation of the train schedule (TS), which is one of the key documents efficiency of railway infrastructure capacity. Schedule of trains is not only a major technological documents for internal use, but also the defining part of the agreement between the carriers and owners of infrastructure and automation solution development TS is one of the most important tasks of planning and management of the railway transport. Methodology. In order to solve the problem in a mathematical model was formed to prepare a timetable of trains, focused on getting the minimum value of the total costs of unproductive idle all trains in the area, the cost of stopping the trains and the cost of the penalty for failure to comply with the deadlines of the trains through the site in accordance with the request of the operators. Simultaneous laying of a large number of trains is reduced to a combinatorial problem relates to the class of NPhard. Findings. In order to solve the mathematical model proposed in the proposed use of the methods of optimization of the multi - artificial bee colony algorithm (ABC), based on the modeling of the behavior of the bees in the natural environment. Experimental calculations have shown the effectiveness of the ABC algorithm to automate the TS. Originality. The first artificial bee colony algorithm has been adapted to the problem of automated plotting of freight trains on the track sections. Practical value. Application of the ABC algorithm in the preparation and adjustment of the regulatory train schedule will allow the development of new decision support system for engineering professionals based on the WEB technology, improve the accuracy of assembly of hydraulic fracturing and its effectiveness as well as provide an opportunity to correct promptly with unconditional satisfaction of the needs in the transport of goods and passengers.

Keywords: train schedule, multi-agent optimization, traffic capacity.

\section{Вступ}

В умовах впровадження Державної програми реформування залізничного транспорту на 2010-2019 роки [1], оптимізації структури управління галуззю, утворення нових підприємств різних форм власності, що здійснюють вантажні та пасажирські перевезення 3 дотриманням недискриманційного доступу до користування об'єктами інфраструктури залізничного транспорту, потребує перегляду існуючий підхід щодо складання нормативного графіку руху поїздів (ГРП) [2, 3].

Задача складання нормативного ГРП повинна розглядатися в єдиному комплексі задач, що забезпечують технічне планування перевізного процесу, тобто плану формування вантажних поїздів та схем оберту пасажирських поїздів, проведення тягових розрахунків та вибору оптимальної ваги поїздів, встановлення оптимальних розмірів руху та станційних інтервалів, раціональне використання локомотивного парку. На даний момент підхід до складання ГРП залишається традиційним, але має ряд недоліків: не здійснюється прив'язка заявки на перевезення до розкладу відправлення поїздів зі станції формування, нормативний графік руху поїздів розробляється без урахування вимог вантажовідправників та вантажоодержувачів, недостатня гнучкість процесу зміни діючого нормативного графіку руху, розробка та аналіз нормативного ГРП здійснюється без урахування ув'язки маршрутів слідування поїздів на великі відстані [4]. 3 метою усунення даних недоліків необхідним є створення єдиного інформаційного середовища на базі автоматизованої системи розробки та аналізу графіку руху поїздів. Дана автоматизована система повинна підтримувати процес планування перевезень вантажів від подачі заявки на перевезення до розробки нитки графіку руху поїздів та його аналі$3 y$.

Починаючи 3 1950-70-х роках наукові дослідження вчених в області удосконалення графіку руху поїздів були спрямовані на застосування ЕОМ для його побудови та оптимізації. У числі найбільш видатних досліджень цього періоду можна відзначити праці А. Д. Каретнікова, А. П. Петрова, В. М. Акулінічева, В. В. Повороженка, Є. М. Тішкіна, Н. А. Самаріної, С. С. Зяброва , Г. І. Державець, Д. Ю. Левіна, Б. Дел Ріо, В. К. Козлова та ін. [4-7]. Аналіз результатів розрахунків за цими методами дає можливість стверджувати, що вони не дозволяють досягти результату, що має практичну значимість, через певну ідеалізованість одержуваних графіків і неприпустимо великих витрат машинного часу.

У 1980-х роках на мережі залізниць СРСР для вирішення завдання 3 автоматизації розро- 
бки графіка руху поїздів було розпочато створення системи централізованого складання графіка руху поїздів. У 1990-х роках розпочато розробку комплексу програм «АРМ інженераграфіста», який на сьогоднішній день експлуатується не тільки на всіх залізницях Росії, але і на залізницях України, Узбекистану, Латвії і в різних проектно-конструкторських інститутах. Разом 3 тим відсутність централізованої бази даних про технічне оснащення мережі залізниць, узгодженої нормативно-довідкової інформації, можливості оперативної передачі даних в рамках єдиного інформаційного простору, збереження істотної частки ручної праці значно знижують ефективність даного програмного комплексу.

\section{Мета}

Метою роботи є формування автоматизованої технології складання нормативного графіку руху поїздів на основі методів мультиагентної оптимізації, яка передбачає в оперативному режимі автоматизоване складання графіку руху поїздів 3 його можливим корегуванням.

\section{Методика}

3 метою більш гнучкого корегування ГРП при ефективному насиченні пропускної спроможності дільниць постає завдання щодо його автоматизованого складання, що відноситься до задач розрахунку розкладу поїздів (англ., Train Timetabling Problem, TTP) [8, 9]. Одночасне прокладання великої кількості поїздів зводиться до комбінаторної задачі, що відноситься до класу NP-складних $[10,11]$.

Для вирішення цієї задачі в роботі запропоновано застосувати один 3 методів мультиагентної оптимізації - алгоритм штучних бджолиних колоній (англ., Artificial Bee colony Algorithm, ABC) [12], який базується на моделюванні поведінки бджіл у природному середовищі.

Згідно до попередніх досліджень [13] математична модель розрахунку графіку руху вантажних поїздів буде мати цільову функцію:

$$
\begin{aligned}
& F=\sum_{j=1}^{n-1}\left[\sum_{i=1}^{m}\left[c_{\text {пої-год }}\left(g_{i, j+1}-t_{i, j+1}-g_{i j}\right)+\delta_{i j} c_{\text {зуп }}\right]\right]+ \\
& +\sum_{\mathrm{j}=1}^{m}\left[\sum_{i=1 ; n} c_{i j}^{\text {штраф }} \max \left(0, g_{i j=L}-D_{i}\right)\right] \rightarrow \min
\end{aligned}
$$

та обмеження

$$
\left\{\begin{array}{c}
g_{i j}-I_{j} \leq g_{i+1 j}-t_{i j} \\
g_{i j}+\tau_{c x j} \leq g_{i+1 j}-t_{i j} \\
g_{i j}+\tau_{m n j} \leq g_{i+1 j}-t_{i j} \\
\sum_{i}^{m} x_{i j}=1, i \in I, j \in J \\
\sum_{j}^{n} x_{i j}=1, j \in J \\
g_{i j=L} \leq D_{i}
\end{array}\right.
$$

де $n$ - остання проміжна станція на дільниці;

$j-$ перегін на дільниці $(j \forall n-1)$;

$i-$ нитка прослідування поїзду $(i \forall m)$;

$m$ - кількість поїздів на дільниці;

$c_{\text {поїз-год }}-$ вартість простою поїзда на проміжній станції;

$g_{i j}$-момент закінчення заняття поїздом $i$ перегону $j$;

$g_{i j+1}$-момент закінчення заняття поїздом $i$ перегону $j+1$;

$t_{i, j+1}$ - час слідування $i$-тим поїздом по $j+1$ перегону;

$\delta_{i j}$ - функція Хевісайда, де $\delta_{i j}=1$, якщо $i$ тий поїзд має зупинку на ј-тому перегоні; $\delta_{i j}=0$, якщо зупинки немає;

$c_{\text {зуп }}$ - витрати, пов'язані 3 погашенням енергії поїзду при зупинці на ј-тому перегоні, що залежать від профілю перегону;

$c_{i j}^{\text {штраф }}$ - вартість штрафу за несвоєчасне прибуття поїзду на станцію призначення;

$L-$ станція призначення поїзду;

$D_{i}-$ директивний строк прибуття поїзду на станцію призначення;

$I_{j}$ - міжпоїзний інтервал на $j$-му перегоні;

$\tau_{c x j}$ - інтервал схрещення;

$\tau_{\text {нnj }}$ - інтервал неодночасного прибуття на $j$-му перегоні.

Адаптуючи принципи живої природи до вирішення оптимізаційної задачі щодо формування автоматизованого розрахунку ГРП, можна представити процес пошуку найкращого джерела нектару колонією бджіл як процедуру побудови оптимального графік руху поїздів (рис. 1). Основна ідея алгоритму АВС - це імітація поведінки бджіл при пошуку нектару. При цьому існує розподіл бджіл на визначені групи - робочі бджоли, бджоли-дослідники та бджоли-розвідники. Тому під їжею розуміється множина точок прибуття поїздів по кожній ни- 
тці графіку, під кількістю знайденого бджолою нектару слід розуміти значення цільової функції, що оцінює знайдений ГРП. Тоді як процес пошуку їжі робочою бджолою можна розглядати як пошук точок прибуття всіх поїздів на кожній станції на дільниці, що визначає один із варіантів ГРП, а роботу бджіл-дослідників - як пошук кращих варіантів прокладання даної нитки, побудованої на попередньому етапі, у визначених межах (локальних областях).

В межах поставленої задачі щодо визначення оптимального нормативного графіка руху поїздів в роботі запропоновано представити графік руху поїздів на дільниці $з$ визначеною кількістю пар поїздів у вигляді джерела їжі для рою бджолиної колонії.

Спочатку проводиться ініціалізація та задаються основні параметри бджолиної колонії: кількість бджіл в колонії $n_{b}$ (на початку роботи алгоритму перша частина колонії складається 3 робочих бджіл, друга частина - 3 бджілрозвідників), бджола - це $h_{b}=\left[g_{12}, g_{i j}, g_{m, n-1}\right]$, максимальна кількість ітерацій $L_{\max }$, початкова кількість бджіл-розвідників $n$ та обмеження максимальної кількості бджіл-розвідників $n_{\max }$. Визначається граничне значення області пошуку $\Delta g_{i j} \in\left[g_{i j}^{\min } g_{i j}^{\max }\right]$ в залежності від часу відправлення та прибуття поїзду на кінцеву станцію 3 урахуванням $D_{i}-$ директивного строку прибуття поїзду на станцію призначення.

На першій ітерації алгоритму АВС створюється область пошуку рішень $G_{j}, j=\overline{1, L}$ для побудови графіку руху поїздів з розбивкою на 1440 хв та виконується запуск робочих бджіл, які випадковим чином створюють нитки поїздів та формують початкові графіки руху поїздів і оцінюють для кожного значення цільової функції $F$. Після цього проходить обмін інформацією з бджолами-дослідниками, які проводять пошук нових джерел нектару в районі $n_{\text {best }}$ кращих значень $з$ ймовірністю (8) та визначають нову дільницю пошуку (9)

$$
\mathrm{p}_{\mathrm{i}}=\frac{f i t_{i}}{\sum_{j=1}^{S} f i t_{j}},
$$

де $f_{i t}$ - одне із значення цільової функції $F$ для конкретного варіанту ГРП.

Таким чином, на джерела нектару з кращими значеннями цільової функції направляється більша кількість дослідників та звужується область пошуку.

Для кожної бджоли-дослідника визначаємо нові точки (прибуття поїзда) в межах визначеної області пошуку

$$
v_{i j}=g_{i j}+\phi_{i j} \cdot\left(g_{i j}-g_{k j}\right),
$$

де $\phi_{i j}$ - випадкове число в діапазоні $[-1 ; 1]$;

$k$ - індекс рішення вибраного випадковим чином 3 колонії $(k=\operatorname{int}($ rand $\cdot L)+1)$.

Бджоли-дослідники виконують пошук нових джерел нектару на своїх ділянках, тобто створюють нитки поїздів, оцінюють $F_{s}$ - одне із значень цільової функції в межах визначеної області пошуку $v_{\mathrm{ij}}$.

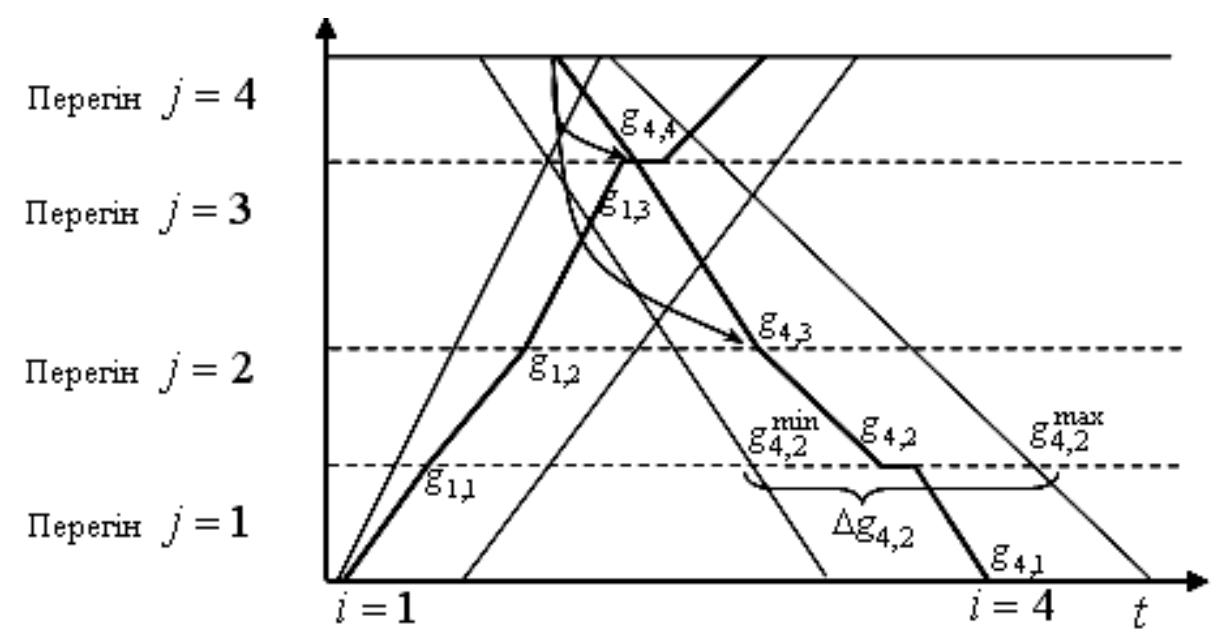

Рис. 1. Графічне уявлення побудови ниток графіку руху вантажних поїздів з використанням методу бджолиної колонії. 


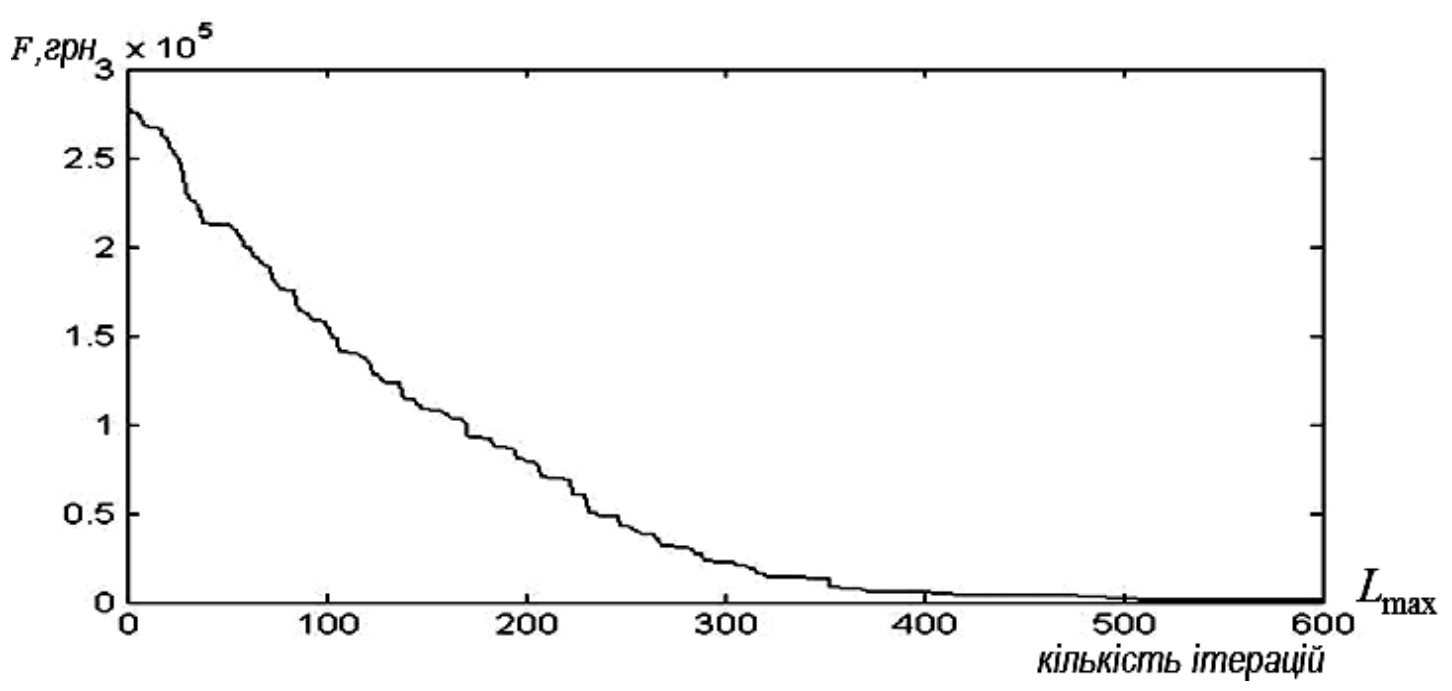

Рис. 2. Графік залежності значень цільової функції $F$ від кількості ітерацій процедури АВС.

Серед $F$ та $F_{s}$ вибирається краще значення цільової функції $F^{*}$, знайдене на цій ітерації спільно роєм розвідників та робочих бджіл. Краще рішення зі значенням $F^{*}$ зберігається, та відбувається перехід до наступної ітерації.

На другій та подальших ітераціях пошук нових джерел нектару відбувається 3 двох частин: включаються кращі рішення $n_{\text {best }}^{*}$, визначені на попередній ітерації, та формуються нові області бджолами-розвідниками випадковим чином. Далі виконуються дії, як і для першої ітерації.

Якщо після заданої кількості ітерацій рішення на даній дільниці не поліпшується, то вона виключається 3 розгляду. Бджолидослідники даної дільниці стають бджоламирозвідниками та відбір рішень проходить випадковим чином. Процес триває до досягнення максимальної кількості ітерацій $L_{\max }$.

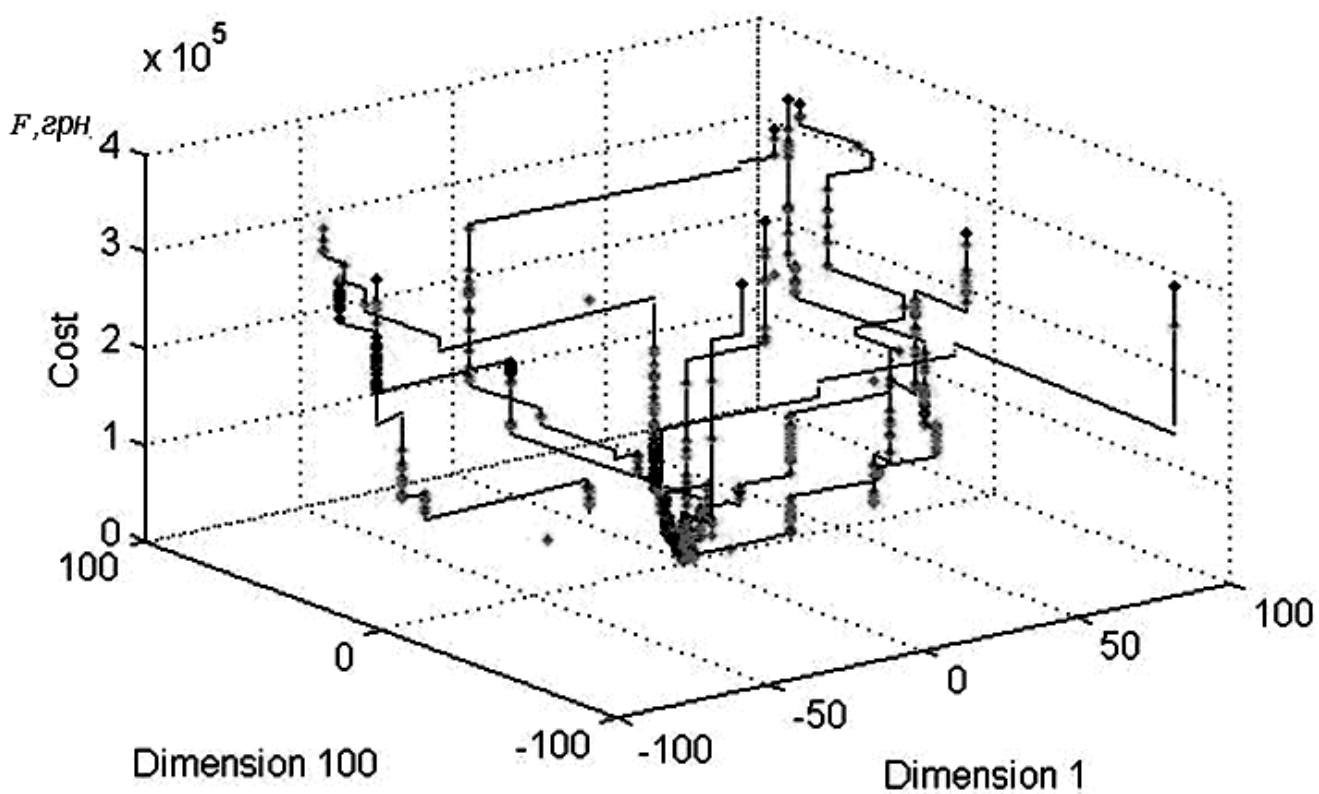

Рис. 3. Знайдені кращі значення цільової функції в тривимірному просторі рішень при складанні графіку руху поїздів за допомогою процедури АВС.

\section{Результати}

Запропонована технологія моделювання колективного інтелекту на основі алгоритму бджолиних колоній створює нові можливості для розрахунку нормативного графіку поїздів 3 проведенням корегування в найкоротші строки для задоволення потреб компаній-перевізників. Приклад роботи представленої моделі АВС реалізовано в середовищі Скайлаб. На рис. 2 наведено динаміку знаходження рішень. На рис. 3 наведено результати складання кращих ниток 
поїздів в довільно створеному середовищі.

\section{Наукова новизна та практична значимість}

В даній науковій роботі вперше алгоритм штучних бджолиних колоній було адаптовано до рішення задачі автоматизованої побудови графіку руху вантажних поїздів на одноколійній дільниці. Застосування алгоритму АВС при складанні та корегуванні нормативного графіку руху поїздів дозволить в найкоротші строки задовольняти потреби компаній-перевізників щодо розподілення пропускної спроможності залізничної мережі з урахуванням обмежень на технічні та технологічні параметри інфраструктури.

\section{Висновки}

На основі вищевикладеного можна зробити висновок, що запропонований метод $є$ ефективним засобом для вирішення оптимізаційної задачі щодо автоматизованого розрахунку ГРП.

Застосування алгоритму АВС для автоматизованого складання нормативного графіку руху поїздів дозволить розробити нові системи підтримки прийняття рішень інженерних працівників на основі WEB-технологій, підвищити точність складання ГРП та його ефективність, а також надасть можливість корегування в оперативному порядку при безумовному задоволенні потреб в перевезенні вантажів та пасажирів.

\section{БІБЛІОГРАФІЧНИЙ СПИСОК}

1. Державна цільова програма реформування залізничного транспорту [Текст] : затв. : Постанова Каб. Мін. України від 16.12.2009 р. № 1390. - Київ. 2009. - $21 \mathrm{c}$.

2. Нестеренко, Г. І. Автоматизована розробка i побудова графіків руху поїздів [Текст] / Г. І. Нестеренко, О.М. Пасічний // Транспортні системи та технології перевезень : Зб. наук. праць Дніпропетр. нац. ун-ту залізн. трансп. ім. акад. В. Лазаряна Дніпропетровськ: ДНУЗТ, 2012. - Вип. 3. - С. 88-94.

3. Мазуренко, О. О. Імітаційна модель роботи залізничного напрямку для дослідження варіантів організації вантажних вагонопотоків в оперативних умовахі [Текст] / О. О. Мазуренко, А. В. Кудряшов // Транспортні системи та технології перевезень : Зб. наук. праць Дніпропетр. нац. ун-ту залізн. трансп. ім. акад. В. Лазаряна - Дніпропетровськ: ДНУЗТ,
2012. - Вип. 3. - С. 50-55.

4. Каретников, А. Д. График движения поездов [Текст] / А. Д. Каретников, Н. А. Воробьев. Москва: Транспорт, 1979. - 301 с.

5. Самарина, Н. А. Составление двухпутного графика движения поездов на ЭВМ [Текст] / Н. А. Самарина. - Москва: Транспорт, 1973. - 123 с.

6. Самарина, Н. А. Применение ЭВМ для разработки графиков движения поездов на направлениях,примыкающих к узлу [Текст] / Н. А. Самарина // Сб. науч. трудов всесоюзного науч-исслед. ин-та ж.д. трансп. - Москва:Транспорт, 1974. - Вып. 517. $-136 \mathrm{c}$.

7. Каретников, А. Д. Совершенствование графика движения поездов и улучшения использования пропускной способности железнодорожных линий [Текст] / А. Д. Каретников, Н. А. Воробьев // Тр. ЦНИИ МПС. - Москва: Трансжелдориздат, 1960. Вып. 203. - 222 c.

8. Caprara, A. Modeling and Solving the Train Timetabling Problem [Text] / Alberto Caprara, Matteo Fischetti, Paolo Toth // Operations Research. - 2002. Vol. 50(5). - P. 851-861.

9. Carey, M. A model, algorithms and strategy for train pathing [Text]/ M. Carey, D. Lockwood // The Journal of the Operational Research Society. - 1995. Vol. 46(8). - P. 988-1005.

10. Dinh Nguyen PHAM Complex Job Shop Scheduling: Formulations, Algorithms and a Healthcare Application/ Dinh Nguyen PHAM [Text] // Thesis presented to the Faculty of Economics and So cial Sciences at the University of Frib o urg (Switzerland). 2008. - $162 \mathrm{p}$.

11. Гери, М. Р. Вычислительные машины и труднорешаемые задачи [Текст] // М. Р. Гери, Д. С. Джонсон. - Москва: Мир, 1982. - 416 с.

12. Karaboga, D. A Powerful and Efficient Algorithm for Numericial Function Optimization: Artifacial Bee Colony(ABC) [Текст] D.Karaboga,B.Basturk // Journal of Global Optimization, 2007. - Vol. 39. - P. 459-471.

13. Бутько, Т. В. Наукові підходи до формалізації процесу автоматизованого складання графіка руху вантажних поїздів [Текст] / Т. В. Бутько, Г. О. Прохорченко // Зб. наук. праць Укр. держ. акад. залізн. тр-ту. - Харків: УкрДАЗТ, 2012. - Вип. 131. C. 31-37.

Стаття рекомендована до публікаиії д.т.н., проф. Ломотько Д. В. (Україна)

Надійшла до редколегії 16.05.2015. Прийнята до друку 17.05.2015. 